\title{
Diverse approaches to crop diversification in agricultural research. A review
}

\author{
Johannes Hufnagel $^{1} \cdot$ Moritz Reckling $^{1,2} \cdot$ Frank Ewert $^{1,3}$
}

Accepted: 12 March 2020 / Published online: 20 April 2020

(C) The Author(s) 2020

\begin{abstract}
Agricultural intensification increased crop productivity but simplified production with lower diversity of cropping systems, higher genetic uniformity, and a higher uniformity of agricultural landscapes. Associated detrimental effects on the environment and biodiversity as well as the resilience and adaptability of cropping systems to climate change are of growing concern. Crop diversification may stabilize productivity of cropping systems and reduce negative environmental impacts and loss of biodiversity, but a shared understanding of crop diversification including approaches towards a more systematic research is lacking. Here, we review the use of 'crop diversification' measures in agricultural research. We (i) analyse changes in crop diversification studies over time; (ii) identify diversification practices based on empirical studies; (iii) differentiate their use by country, crop species and experimental setup and (iv) identify target parameters to assess the success of diversification. Our main findings are that (1) less than $5 \%$ of the selected studies on crop diversification refer to our search term 'diversification'; (2) more than half of the studies focused on rice, corn or wheat; (3) $76 \%$ of the experiments were conducted in India, USA, Canada, Brazil or China; (4) almost any arable crop was tested on its suitability for diversification; (5) in $72 \%$ of the studies on crop diversification, at least one additional agronomic measure was tested and (6) only $45 \%$ of the studies analysed agronomic, economic and ecological target variables. Our findings show the high variability of approaches to crop diversification and the lack of a consistent theoretical concept. For better comparability and ability to generalise the results of the different primary studies, we suggest a novel conceptual framework. It consists of five elements, (i) definition of the problem of existing farming practices and the potential need for diversification, (ii) characterisation of the baseline system to be diversified, (iii) definition of the scale and target area, (iv) description of the experimental design and target variables and (v) definition of the expected impacts. Applying this framework will contribute to utilizing the benefits of crop diversification more efficiently.
\end{abstract}

Keywords Cropping systems $\cdot$ Cultivation method $\cdot$ Diversity $\cdot$ Experiments $\cdot$ Resilience $\cdot$ Simplification $\cdot$ Specialisation

\section{Contents}

1. Introduction

2. Methodology

2.1 Search term strategy

2.2 Analysed information

Johannes Hufnagel

jhufnagel@zalf.de

1 Leibniz Centre for Agricultural Landscape Research (ZALF), Eberswalder Str. 84, 15374 Muencheberg, Germany

2 Department of Crop Production Ecology, Swedish University of Agricultural Sciences (SLU), 75007 Uppsala, Sweden

3 Institute of Crop Science and Resource Conservation, University of Bonn, 53115 Bonn, Germany
3. Global analysis of crop diversification studies

3.1 Historical development and scope of the term 'crop diversification'

3.2 Baselines of crop diversification

3.3 Countries of crop diversification experiments

3.4 Types of crop diversification

3.5 Agronomic measures accompanying crop diversification

3.6 Target variables of the crop diversification experiments

4. The lack of a concept of crop diversification

5. Methodological considerations

6. Conclusion

Acknowledgments

References 


\section{Introduction}

Agriculture has developed towards intensive but simplified production systems over the last decades, especially in the northern Hemisphere. While this trend significantly increased agricultural productivity, it also had detrimental effects on the cropping systems themselves and on the environment (Tilman et al. 2002). A multitude of driving forces led to lower diversity of cropping systems like, e.g. easy availability of mineral fertilisers and pesticides, concentration of breeding efforts on the economically most important crops and changes in agricultural policies that allow producers to respond more freely to market signals, incentives and technology change (Fausti 2015). These processes supported a higher genetic uniformity within crop species (Kahiluoto et al. 2019), less crop species in rotations (Stein and Steinmann 2018; Barbieri et al. 2017) and higher uniformity within agricultural landscapes (Fig. 1) with large field sizes (Bianchi et al. 2006; Rusch et al. 2016). This development also caused environmental problems such as nitrate pollution of water, eutrophication of ecosystems, climate-relevant emissions of greenhouse gases (Bommarco et al. 2013; Therond et al. 2017; Bowles et al. 2018; Stoate et al. 2009) and an overall loss of habitats and biodiversity (Tscharntke et al. 2012; Kleijn et al. 2012; Buhk et al. 2017; Frison et al. 2011; Therond et al. 2017; Bommarco et al. 2013).

Simplification of farming systems and growing environmental problems led to concerns about the future functionality of today's cropping systems with regard to resilience, adaptability to climate change, multifunctionality of agricultural landscapes, provisioning of ecosystem services and biodiversity (Lichtenberg et al. 2017; Rusch et al. 2016).
Crop diversification can be considered as an attempt to increase the diversity of crops through, e.g. crop rotation, multiple cropping or intercropping (Fig. 2), compared to specialized farming with the aim to improve the productivity, stability and delivery of ecosystem services (Kremen et al. 2012; Garbach et al. 2017; Wezel et al. 2014). It can be one measure to develop more sustainable production systems, develop value-chains for minor crops (Meynard et al. 2018) and contribute to socio-economic benefits (Feliciano 2019). Crop diversification practices can include higher crop diversity (Renard and Tilman 2019), more diverse crop rotations (Reckling et al. 2016), mixed cropping (Bedoussac et al. 2015; Malézieux et al. 2009), cultivation of grain legumes in otherwise cereal dominated systems (Watson et al. 2017), perennial leys or grassland (Haughey et al. 2018; Phelan et al. 2015; Weißhuhn et al. 2017) and regionally adapted varieties or variety mixtures (Yang et al. 2019; Vijaya et al. 2019). Crop diversification and/or additional diversification measures like variation of seeding time or changing cropping patterns have the potential to lead to higher and more stable yields, increase profitability and lead to greater resilience of agro-ecosystems in the long term (Rosa-Schleich et al. 2019; Meynard et al. 2018; Liu et al. 2019; Raseduzzaman and Jensen 2017; Renard and Tilman 2019; Urruty et al. 2016). These practices have the potential to make cropping systems more divers in space, time and genetics. Consequences of diversification are temporal shifts and ranges of phenological stages (relevant for biodiversity and adaptation to climate change), more frequent or continuous soil cover and more diverse management strategies, i.e. 'tillage', 'sowing dates', 'fertilization', 'irrigation', 'harvesting' and also reducing labour peaks and economic risk.
Fig. 1 Aspect of a large field of winter rye in a simplified cropping system in Northern Brandenburg, Germany. Copyright Johannes Hufnagel

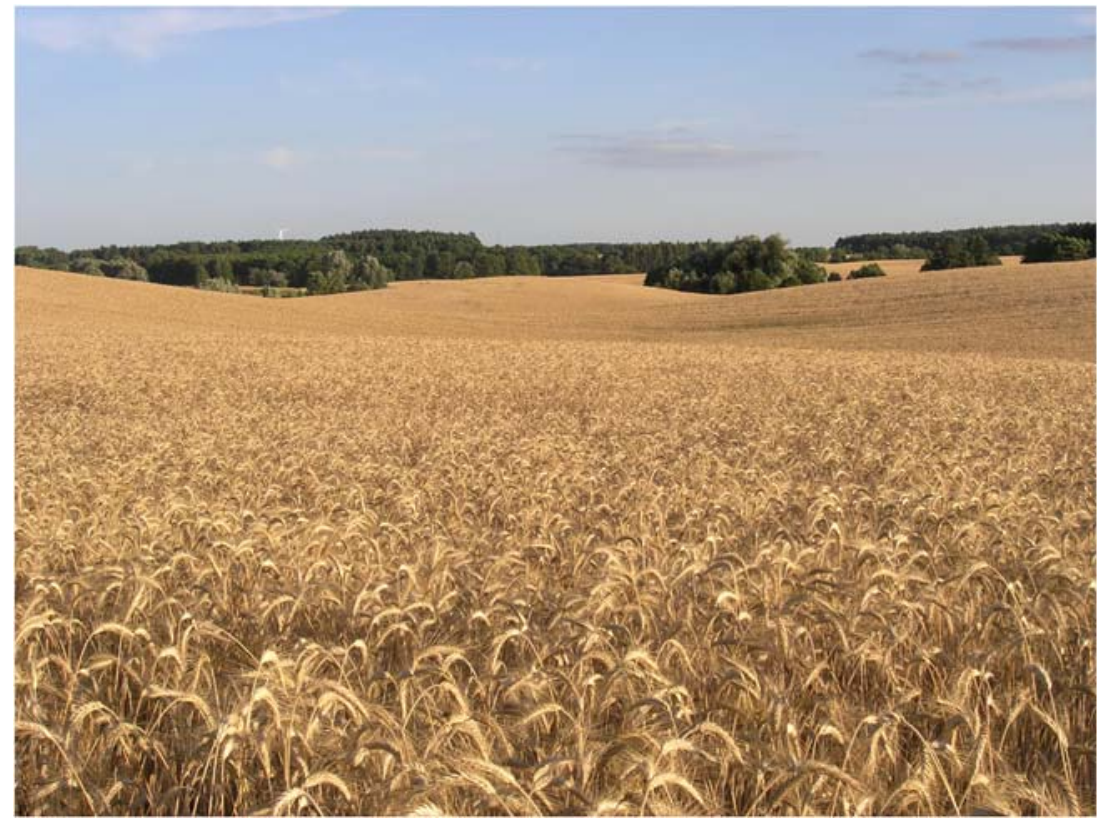


Fig. 2 Intercropping maize with climbing beans diversifies current crop rotations in Northern Germany. Here, maize serves as a pole for the red-flowering scarlet runner bean (Phaseolus coccineus L. cv Preisgewinner) before both crops are harvested for silage (Fischer et al. 2020). Copyright: Jenny Fischer/Thünen Institute of Organic Farming

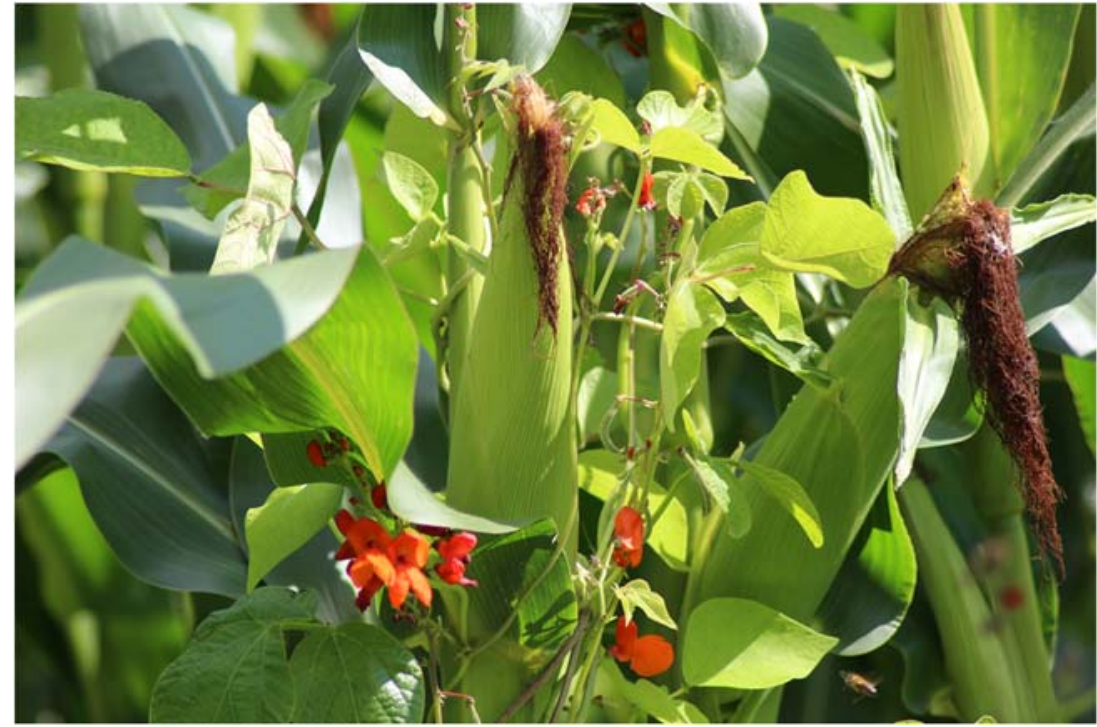

Davis et al. (2012) showed that diverse cropping systems provided similar or even higher yields than simplified systems whilst environmental impacts were lower. Renard and Tilman (2019) found that arable crop species diversity at national level is correlated with greater year-to-year stability of the total national harvest of all edible crops. Nevertheless, measures of diversification are rarely implemented because of lack of required investments in machinery, infrastructures and expertise and research evidence (Meynard et al. 2018; Roesch-McNally et al. 2018; Ponisio and Ehrlich 2016; Geels 2011).

A closer look on 'diversification' reveals that the term lacks a clear definition and from this reason, it is used in very different meanings. Some authors only use the term to describe diversification by crops, e.g. mixed cropping; others restrict it to diversification by management strategies, e.g. varying seeding time. Some use it for a combination of cropping and management approaches. The same applies for the scale analysed: Investigations are done from on field, farm and landscape level.

The very complex diversification approach of 'diversified farming systems' as described, e.g. by Kremen et al. (2012) and Rosa-Schleich et al. (2019), rely on diversification concepts that apply individual steps of crop diversification, e.g. cover crops, and diversification by management strategies, e.g. reduced tillage at the field level, production systems at the farm level (e.g. 'organic farming', 'conservation agriculture') and selected measures at the landscape level (e.g. 'structural elements'). In the diversified farming approach, it is not obvious which diversification measures are chosen under what conditions. The choice of the combination of measures seems to rely on diversity concepts and depends on, inter alia, which ecosystem services (ES) are in focus.
As diversification is a relatively new as a concept, many authors may not use the term diversification at all although their main focus is on diversification. An extensive metastudy at global scale analysed the effects of crop diversification on numerous parameters (Beillouin et al. 2019a), and many of the articles evaluated do not use the term diversification. Although the term has recently been shown more frequently in agronomic studies (Hatt et al. 2018; Haro et al. 2018; Kumar et al. 2017; Hondrade et al. 2017), many publications still mention only the tested diversification measure, e.g. intercropping.

In many different contexts, there is no clear separation between the concepts of diversification and 'diversity'. Although research on crop diversity has increased, it mainly refers to natural and semi-natural systems. In most cases, ecologists analysed the simultaneous occurrence of system diversity with biodiversity (Cardinale et al. 2007; Gross et al. 2014). As a consequence, authors suggest to apply (agro) ecological principles of diversity to agricultural systems to make these more resilient (Wezel et al. 2014; Landis 2017; Altieri et al. 2015; Barot et al. 2017; Therond et al. 2017; Isbell et al. 2017). In many cases, the concept of diversity is seen as equal to the concept of diversification. From an agronomic point of view, that is not the case: while the former deals with biological principles such as genetic diversity, the latter deals with agronomic principles such as crop rotation or mixed cropping that subsequently might lead to higher biodiversity and associated ecosystem services. Diversification is the process that leads to the state of diversity. Depending on the initial situation, the same measure of crop diversification might lead to completely different states of biodiversity or ecosystem services. Although diversification is claimed to be a fundamental solution for many problems of today's 
agricultural systems (Renard and Tilman 2019), sufficient quantitative evidence is lacking from long-term studies (Reckling et al. 2019).

In this review, we focus on crop diversification and define it as 'a process that makes a simplified cropping systems more divers in time and space by adding additional crops'. Crop diversification can lead to greater genetic and/or structural diversity in time and/or space. Common examples for crop diversification are crop rotations, double cropping or intercropping, bee crops, nurse crops or variety mixtures. Diversification by agronomic measures, e.g. tillage, shall not be considered unless it is tested in combination with crop diversification. Our analysis was restricted to crop diversification at the field level. In contrast to many studies, we have taken an agronomic perspective on crop diversification as a basis for this review.

This review aims to elucidate the current use of crop diversification in research and support a common approach to utilize its full potential. We argue that a common understanding of the diversification concept in the context of crop production is needed for enabling the comparison of results and to enhance the empirical evidence of the effects of diversification as a measure to make cropping systems more resilient and to reduce negative impacts on the environment. Generally spoken, our main questions were: Is there a common understanding of crop diversification as a concept within the scientific community of agronomist regarding topic, scope and 'successful' application? And do we agree on the methods to test crop diversification in field experiments in order to achieve scientifically sound and transferable results? The objectives of this paper were to (i) review the use of crop 'diversification measures' in agricultural research; (ii) describe changes in using the term diversification over the last 40 years; (iii) identify the most common temporal and spatial practices of crop diversification like crop rotation or intercropping based on empirical studies; (iv) differentiate their use by country, crop species and experimental setup and (v) identify target parameters that were analysed.

\section{Methodology}

\subsection{Search term strategy}

Since we did not find a classification system of crop diversification, we defined a list of crop diversification measures that consider the most important steps of crop diversification. The search terms used were based on different references (Connor et al. 2011; Wezel et al. 2014; Malézieux et al. 2009; Hole et al. 2005) and focused exclusively on crop diversification (e.g. expansion of crop rotation, implementation of flower strips) at the field scale. The search terms were not exhaustive and overlaps between categories were unavoidable.

The material for the review was selected by searching the Scopus database (www.scopus.com). The relevant search terms were applied to 'article title', 'abstract' and 'keywords'. The search was restricted to Source type 'journals'; to Document types 'article', 'review' and 'articles in press' and to Language 'English'. The decisive search was done the 18th of June 2018 and included all references available in the Scopus database to this date.

The selection of the literature analysed followed a three-step procedure: (i) searching for publications tagged with different target terms for 'measures of crop diversification' using specific terms for each measure and related terms differentiated by temporal and spatial crop diversification (Table 1), (ii) filtering the publications from step 1 that were tagged with diversification or related search terms (Table 2) and (iii) selecting the publications from the remaining sample that documented results from field experiments in arable farming. If the main focus of the experiment was on arable farming publications of adjacent fields like 'field vegetables', 'pastures' or 'alley cropping' were selected too.

The search terms we used for selecting publications on crop diversification (Table 1) are the iterative outcome of more than 30 provisional searches done with the objective to explore and understand the topic area and find the most suitable search terms.

The search for measures of crop diversification resulted in 43,680 hits (step 1), 19,305 for 'temporal' and 24,375 for 'spatial crop diversification'. Selecting those publications that were tagged with diversification (step 2) led to 680 hits, thereof 16 were totally out of focus, 417 treated the topic with a non-experimental view such as meta-analysis, reviews, models, farmer surveys or reported about diversification in adjacent subject areas like aquaculture, pure agroforestry, fruits or forests. The remaining 247 publications reported about field experiments in arable farming. Some of them reported about two or three different measures of crop diversification thus been selected twice or three times by the selection procedure described. For this reason, in the end, the review is based on 193 primary studies.

\subsection{Analysed information}

The subsequent analysis of the selected literature was performed manually extracting information from article titles, keywords and abstracts available in Scopus. When information was lacking or too vague, 'material and methods' of the full article was consulted. 
Table 1 Measures of crop diversification, its characterisation, list of search terms applied and number of hits by measure of crop diversification (17th of June 2018)

\begin{tabular}{|c|c|c|c|}
\hline $\begin{array}{l}\text { Measure of crop } \\
\text { diversification }\end{array}$ & Characterisation & Search terms applied (connected with 'or') & $\begin{array}{l}\text { Number of } \\
\text { Hits }\end{array}$ \\
\hline Temporal crop diversification & & & 19,305 \\
\hline Crop rotation & $\begin{array}{l}\text { Growing of two or more different crops in } \\
\text { consecutive growing seasons }\end{array}$ & $\begin{array}{l}\text { 'crop }{ }^{\mathrm{b}} \text { rotation', 'crop }{ }^{\mathrm{b}} \text { sequence', 'sequential crop }{ }^{\mathrm{b}} \text {, } \\
\text { 'successive crop b', 'ley farming', 'sequence of } \\
\text { plant species', 'sequence of crops' }\end{array}$ & 12,693 \\
\hline Double to multiple cropping & $\begin{array}{l}\text { Growing of two or more different crops in } \\
\text { one growing season }\end{array}$ & 'double crop', 'multiple crop' ${ }^{\mathrm{b}}$, 'phased planting' & 2421 \\
\hline Catch crops & $\begin{array}{l}\text { Minor crops planted before, between or } \\
\text { after a major crop }\end{array}$ & $\begin{array}{l}\text { 'catch crop }{ }^{\mathrm{b}}, \text { 'stubble crop }{ }^{\mathrm{b}}, \text { ' 'live mulch', } \\
\text { 'green manure' }\end{array}$ & 4020 \\
\hline Relay cropping ${ }^{\mathrm{a}}$ & $\begin{array}{l}\text { The seeding of one crop into another } \\
\text { standing crop and thus growing two } \\
\text { crops simultaneously for a certain time }\end{array}$ & 'relay crop' & 171 \\
\hline Spatial crop diversification & & & 24,375 \\
\hline Alley cropping & $\begin{array}{l}\text { The simultaneous growing of arable } \\
\text { and perennial crops in different } \\
\text { broader strips }\end{array}$ & 'alley crop' & 717 \\
\hline Intercropping & $\begin{array}{l}\text { Simultaneous growing of at least } 2 \text { crops } \\
\text { in different yet proximate rows }\end{array}$ & 'intercrop ${ }^{\mathrm{b}}$, 'strip crop $\mathrm{b}$, & 7659 \\
\hline Mixed cropping & $\begin{array}{l}\text { Simultaneous growing of at least two } \\
\text { crops } \\
\text { in the same field but not in rows }\end{array}$ & $\begin{array}{l}\text { 'mixed crop }{ }^{\mathrm{b}} \text { ', 'mixed plant }{ }^{\mathrm{b}} \text {, 'biculture', } \\
\text { 'triculture', 'multiple crop }{ }^{\mathrm{b}} \text { ', 'polyculture', } \\
\text { 'species mixture', 'plant teams' }\end{array}$ & 5531 \\
\hline Companion crops & $\begin{array}{l}\text { Special form of mixed cropping. } \\
\text { Simultaneous sowing of at least two } \\
\text { crops. One of it is used in the year(s) } \\
\text { after sowing }\end{array}$ & $\begin{array}{l}\text { 'companion crop b', 'cover crop b', 'cover plant }{ }^{\mathrm{b}} \text {, } \\
\text { 'nurse crop", 'underplanting', 'undersowing' }\end{array}$ & 6756 \\
\hline Variety mixtures & $\begin{array}{l}\text { Growing of two or more varieties } \\
\text { of one species }\end{array}$ & $\begin{array}{l}\text { 'variety mixture }{ }^{\mathrm{b}}, \text { 'mixture of varieties', 'cultivar } \\
\text { mixture }{ }^{\mathrm{b}} \text {, } \\
\text { mixed cultivar', 'genetic mixture }^{\mathrm{b}} \text { ' }\end{array}$ & 294 \\
\hline Bee plants & $\begin{array}{l}\text { Mixture of commercial and non- } \\
\text { commercial crops on the same } \\
\text { field (to support insects, etc.) }\end{array}$ & $\begin{array}{l}\text { 'flower plant }{ }^{\mathrm{b}} \text {, 'flower crop }{ }^{\mathrm{b}} \text { ', 'bee plant }{ }^{\mathrm{b}} \text {, 'bee crop }{ }^{\mathrm{b}} \text {, } \\
\text { 'flower strip }\end{array}$ & 2803 \\
\hline Trap crops & $\begin{array}{l}\text { Mixture of commercial and non- } \\
\text { commercial crops on the same } \\
\text { field to control pests or diseases }\end{array}$ & 'trap crop", 'barrier crop" & 615 \\
\hline
\end{tabular}

${ }^{\text {a }}$ Initially spatial than temporal cropping

${ }^{\mathrm{b}}$ Wildcard, it represents 0 or more characters

Based on the extracted information, the following questions were to be answered:

1) How did the number of articles about 'crop diversification' develop over time, are there differences between temporal and spatial diversification?

(2) How did experiments on crop diversification develop over time?

(3) What was the experimental baseline ('control') against which crop diversification was compared to?

(4) Where (which countries) were experiments on crop diver sification executed and what were the main baselines in these countries?

(5) What measures of crop diversification were analysed experimentally?

(6) Was crop diversification combined with additional agronomic measures and if so, by which?
(7) Which target variables were analysed to evaluate the impact of crop diversification?

\section{Global analysis of crop diversification studies}

\subsection{Historical development and scope of the term crop diversification}

The number of publications with the focus on crop diversification that use the term diversification increased slowly from far below 10 per year in the 1980 s to about 25 in the 2010s and tripled to almost 100 in 2017 (Fig. 3). The share of publications on temporal vs. spatial diversification was similar over the years with an average of $47 \%$ and $53 \%$, respectively. Only in years with very few publications (e.g. 1985, 1995), the 
Table 2 Target term 'Diversification' and list of search terms applied

\begin{tabular}{ll}
\hline Target term & Search terms applied (connected with 'or') \\
\hline Diversification & 'diversification', 'diversified farming', 'diversified crop", 'diversified production', 'diversified agro', 'diversified agria
\end{tabular}

${ }^{\mathrm{a}}$ Wildcard, it represents 0 or more characters

share varied significantly between 0 and 100\% (Fig. 3). The number of experiments on diversification developed more or less parallel to the number of studies on crop diversification in general. There were only 8 years without any studies reporting experiments that tested measures of diversification and referring to the concept of diversification, between 1981 and 1995 (Fig. 3). The share of publications reporting about experiments in years with 10 and more publications varies between 9 and $69 \%$ with an average of $44 \%$. Over the whole period, on average, $51 \%$ of the experiments focussed on temporal and $49 \%$ on spatial diversification. The absolute number of 193 primary studies was surprisingly low compared to the high number of publications selected by our search terms on measures of crop diversification (43,680 hits) and the fact that diversification seems to be a very popular concept (Meynard et al. 2018; Rosa-Schleich et al. 2019; Beillouin et al. 2019a; Renard and Tilman 2019). Beillouin et al. (2019a) found almost 20-fold more primary studies on crop diversification measures with a focus on meta-analysis and different search equations. Even though Beillouin et al. (2019a) analysed additional strategies of diversification such as agroforestry and landscape heterogeneity in many articles, they extracted analysed rotations, intercropping, cover crops etc. without mentioning the concept of diversification explicitly.

In our analysis, we found that on average, only $1.6 \%$ of the publications on common measures of crop diversification we selected in step 1 were tagged with the term diversification with only small differences $(0.4-5.1 \%)$ between the different categories of crop diversification (Fig. 4). Among the selected categories on crop diversification (Table 1), the most common measures were 'crop rotation' (12,693 in total and 240 associated with diversification), 'intercropping' (7659 and 141), 'companion crops' (6756 and 63), 'mixed cropping' (5531 and 106), 'catch crops' (4020 and 33), 'bee plants' (2803 and 11) and 'double crops' (2421 and 32). Less common were the measures 'alley crops' (717 and 7), 'trap crops' (615 and 9), 'variety mixtures' (294 and 15) and 'relay crops' (171 and 7). The small number of publications tagged with diversification could be an indication that the concept of diversification is still relatively new in the scientific agricultural community.

In sum, only 193 of the 664 selected publications refer to experiments. The proportion of experiments varies
Fig. 3 Number of publications on temporal and spatial crop diversification per year between 1978 and 17th of June 2018 (total $n=664)$ and number of publications that are based on experimental data $(n=247)$ : black dots: based on experiments

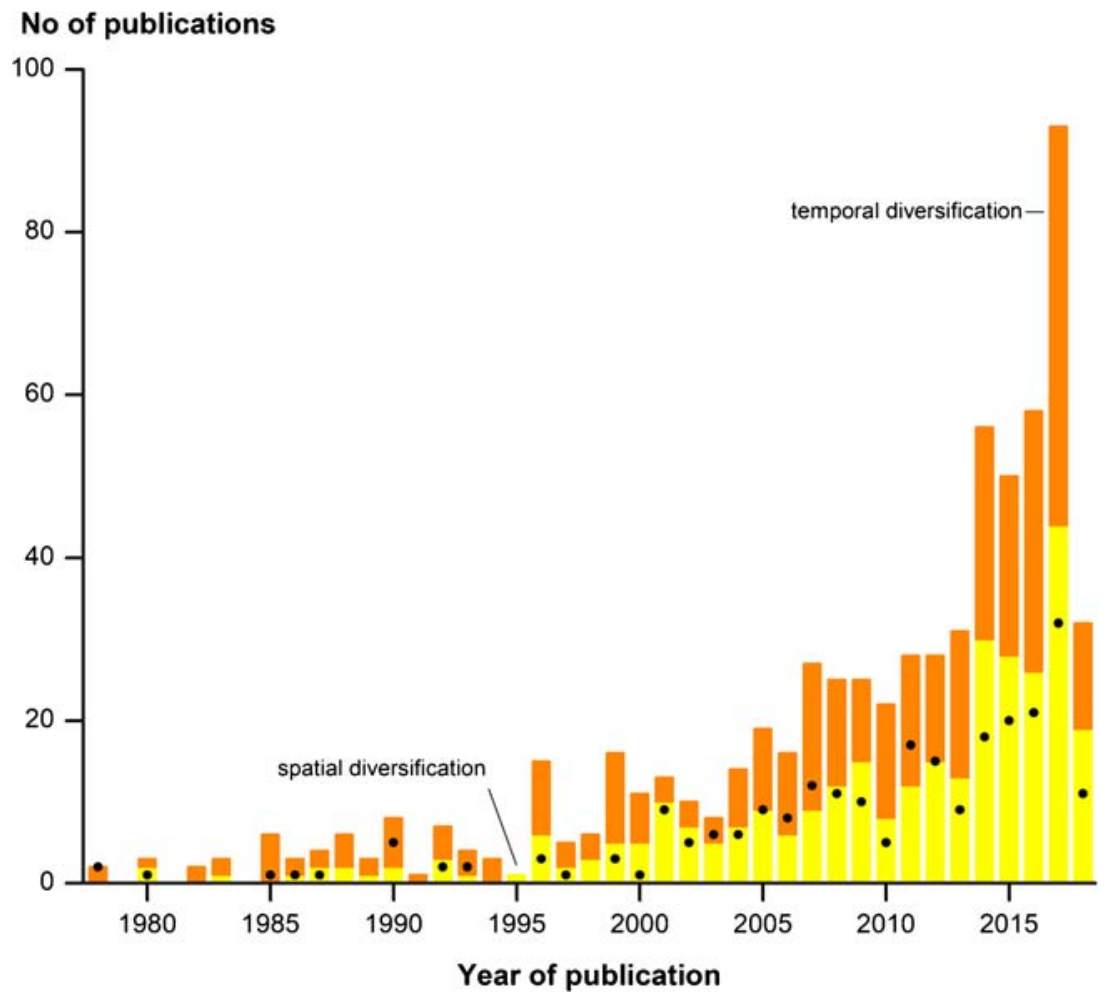


Fig. 4 Number of publications based $(n=247)$ and not based $(n=417)$ on experiments broken down by 'measures of crop diversification'. Column of figures on the right: number of publications by search term $x$ 1000 (total $n=43.6 \times 1000$ ); in brackets: percentage of publications that are tagged with the term 'diversification'

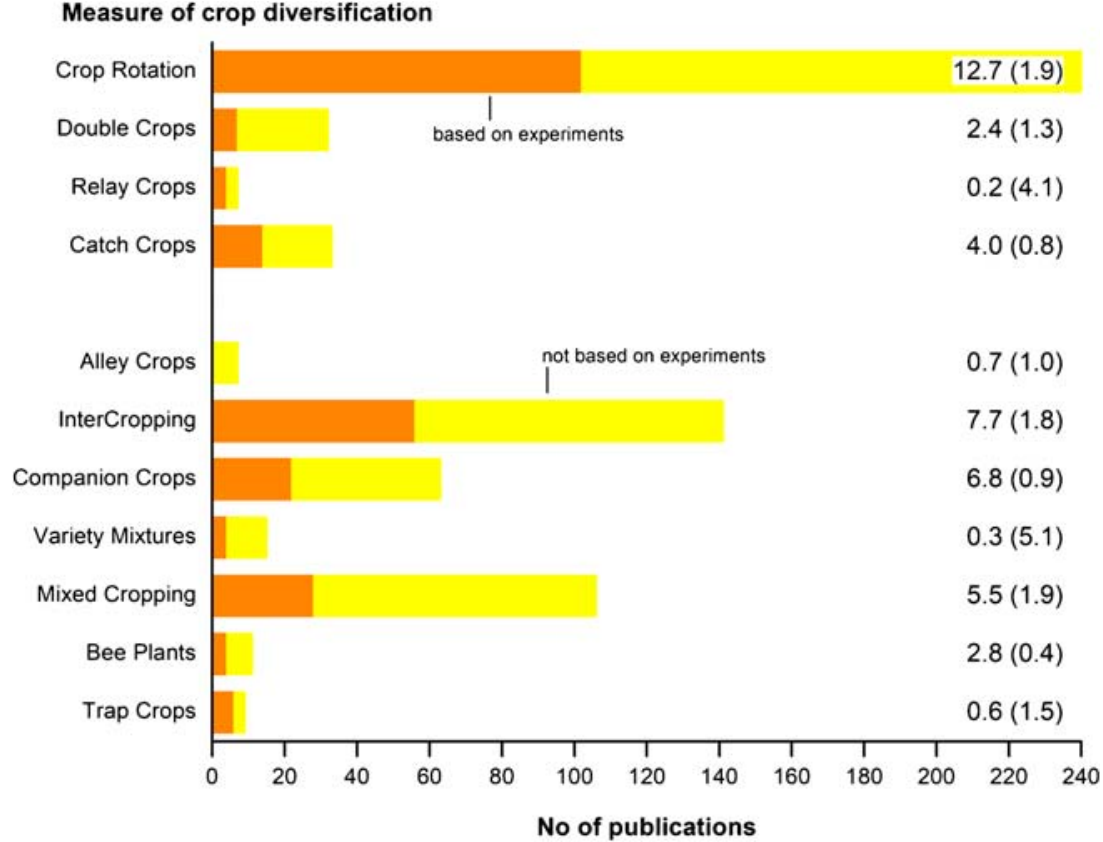

considerably between the different crop diversification strategies and is usually well below $50 \%$ (Fig. 4).

\subsection{Baselines of crop diversification}

Here, we define 'baseline' as the current cropping practice for a given region that is to be diversified in order to improve the performance of an existing system. In most cases, the baseline is part of an experiment and usually regarded as control treatment. In most publications, the baseline of an experiment is explicitly mentioned (control), but in some cases, we had to deduce the baseline by checking further information provided by an article. In many cases, baseline is a simplification of a complex cropping system. Based on our analysis, we identified three simplified types of baselines (Table 3) which comprise approximately the same proportion of publications: pure stands of single crops $(n=59)$, continuous cropping of a single crop $(n=58)$ and simple crop rotations with 2 or maximally 3 crops $(n=76)$.

Pure stands of arable crops $(n=35)$ and field vegetables $(n=24)$ account for the largest types of baselines (Fig. 5). Publications on continuous cropping of a single crop are mainly restricted to wheat, corn or rice while publications on continuous cropping of crops like cotton, soybean or millet play a minor role (Fig. 5). Rotations with two crops are widely represented by rice-wheat $(n=34)$ or corn-soybean or wheat $(n=21)$ while 'wheat and a second crop' is tested less frequently $(n=6)$. The group of 'other simple crop rotations' $(n=15)$ is very heterogeneous with various sequences of two to three crops. In experiments with pure stands as baseline, the starting point for experiments is on genetic homogeneity of one field in a single year. In these experiments, mostly, the focus is on spatial diversification and not on crop rotation. The main crops tested in pure stands are arable crops like pulses including soy $(n=19)$, corn $(n=12)$ and field vegetables like cabbages $(n=15)$ in particular broccoli $(n=9)$ (Table 4). The results show that the starting point for crop diversification experiments is globally restricted to very few crops. In more than $54 \%$ of the primary studies, the main focus is on rice, corn or wheat, which, although economically very important, only represent part of the manifold global cropping situations.

Table 3 Type of baselines and their characterisation

\begin{tabular}{ll}
\hline Type of baseline & Characterisation and focus of experiments \\
\hline Pure stands & $\begin{array}{c}\text { Both arable crops and field vegetables; genetically homogenous crop stands; most experiments are focussed } \\
\text { on spatial (crop) diversification } \\
\text { Mostly arable crops; cropping of one single crop over many years or seasons on the same field; most experiments } \\
\text { are focussed on temporal diversification } \\
\text { Repeated rotation of 2, seldom } 3 \text { crops on the same field; most experiments are focussed on temporal diversification }\end{array}$ \\
Simple crop rotations & Repping
\end{tabular}


Fig. 5 Number of publications on crop diversification experiments broken down by 'baselines' (total $n=193$ )

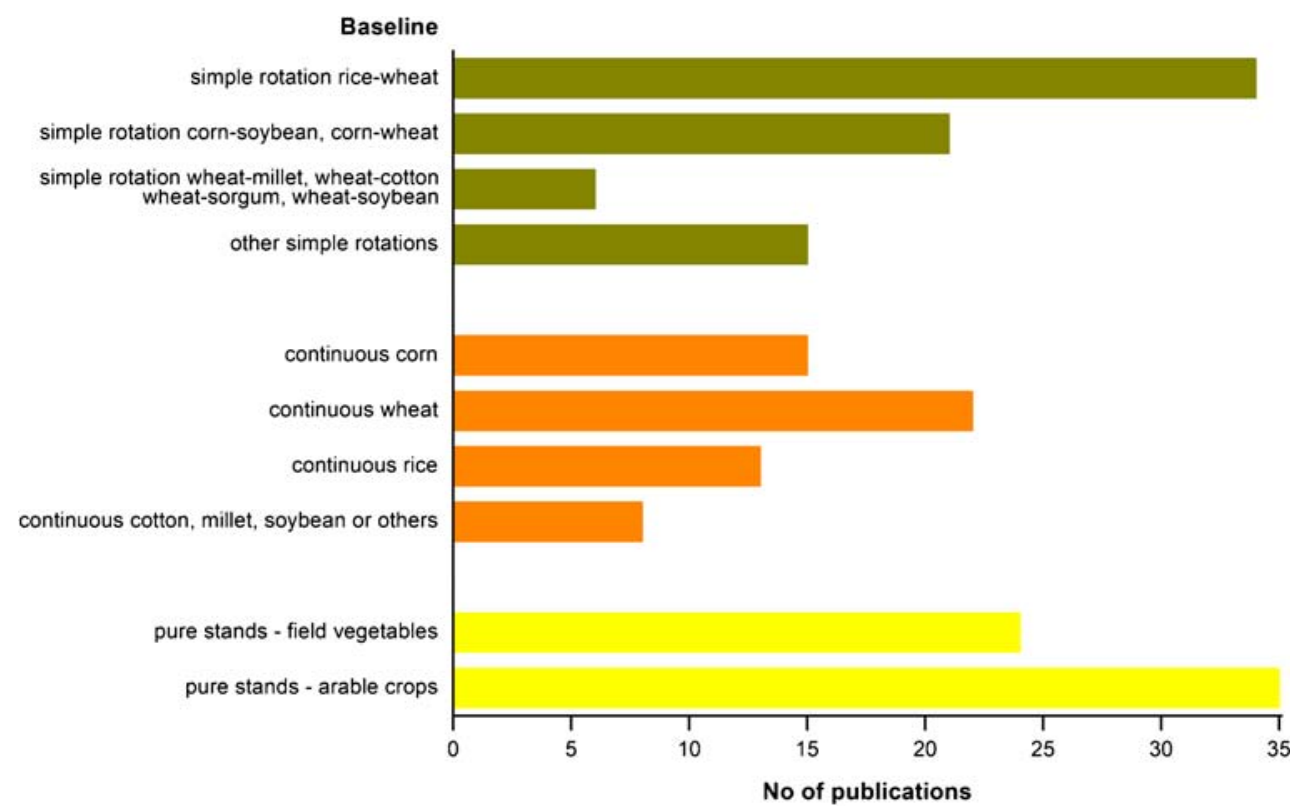

publications is concerned ( $n=46$, all remaining countries together).

According to the analysed literature, experiments with pure stands of arable crops as baselines were mainly carried out in USA, Brazil, India, Finland and China, while those with pure stands of field vegetables were found mainly in the USA, followed by Australia, China and Brazil. Experiments on continuous wheat concentrate in the USA and Canada; very few were carried out in Kazakhstan, China and Australia. In India, $71 \%$ of the experiments were dedicated to diversify continuous rice and rice-wheat rotations while crop rotations with corn and soybean or wheat were mainly tested in the USA, some in India, Argentina and China. Most of the diversification experiments on 'simple crop rotations' were located in Europe and Canada. It seems that the number and kind of baselines that were to be diversified in experiments reflects very much the simplified cropping situation that is widespread in the respective country or region. It was a surprising result of the review that a relevant number of experiments on crop diversification were conducted only in a few countries and thus agroecological situations. This fact limits the ability to generalise the results of the primary studies.

\subsection{Types of crop diversification}

The vast majority of analysed experiments (90\%) were diversified through introducing a 'new' crop into the baseline cropping system: either by temporal diversification $(n=$ 102) - expanding continuous cropping of a single crop or a simple crop rotation - or by spatial diversification $(n=71)$ of a pure stand on a single field through, e.g. intercropping, mixed cropping or companion cropping. The groups of crops used for diversification include the whole range of crop plants 
Table 5 Number of publications on crop diversification in North and South America, Europe, Africa and Asia with Australia broken down by different baselines (numbers in brackets refer to the respective countries)

\begin{tabular}{|c|c|c|c|c|c|c|}
\hline & Baselines & North America (USA) & South America (Brazil) & Europe & Africa & $\mathrm{Asia}^{\mathrm{a}}$ (India) \\
\hline \multirow[t]{4}{*}{ Simple crop rotations } & Others & 3 & 1 & 8 & 2 & 1 \\
\hline & Wheat-millet, cotton, sorghum or soybean & 1 & $1(1)$ & & & $4(4)$ \\
\hline & Rice-wheat & & & & & $34(34)$ \\
\hline & Corn-soybean or wheat & $14(13)$ & 2 & & & $5(3)$ \\
\hline \multirow[t]{4}{*}{ Continuous cropping } & Cotton, millet, Soybean, others & $4(4)$ & $1(1)$ & & 1 & $2(2)$ \\
\hline & Wheat & $18(9)$ & & & & 4 \\
\hline & Rice & & & & & $13(9)$ \\
\hline & Corn & $6(5)$ & $2(2)$ & 1 & 2 & $4(4)$ \\
\hline \multirow[t]{2}{*}{ Pure stands } & Field vegetables & $10(9)$ & $3(3)$ & 2 & 2 & $6(1)$ \\
\hline & Arable crops & $7(7)$ & $8(6)$ & 8 & 4 & $8(4)$ \\
\hline Total & & $63(47)$ & $18(13)$ & 20 & 11 & $81(61)$ \\
\hline
\end{tabular}

${ }^{\mathrm{a}}$ Including Australia $(n=3)$

like cereals, pulses, fodder legumes, grasses, field vegetables and flowers or a combination of 2 or 3 groups of the latter (Fig. 6).

Crop diversification by non-legumes was widespread in experiments of pure stands of field vegetables and arable crops and was still relevant both in continuous corn and wheat and in simple crop rotations (Fig. 6). Both, legumes and non-legumes, were tested to diversify baselines - either alone or both; diversification by pulses and/or fodder legumes alone plays a minor role in crop diversification. The introduction of both nonlegumes and pulses is a central diversification step in rice- wheat rotations, in continuous wheat, continuous rice and continuous corn, in simple crop rotations and in pure stands of arable crop. The introduction of both non-legumes and fodder legumes is tested in corn-soybean or wheat rotations, ricewheat and pure stands of field vegetables, while the introduction of pulses, fodder legumes and non-legumes is widespread in rice-wheat rotations and is of certain importance in continuous corn and continuous wheat and in simple crop rotations (Fig. 6).

Crop diversification by flowers is mainly applied in experiments of field vegetables in pure stands and only sometimes in pure stands of arable crops.

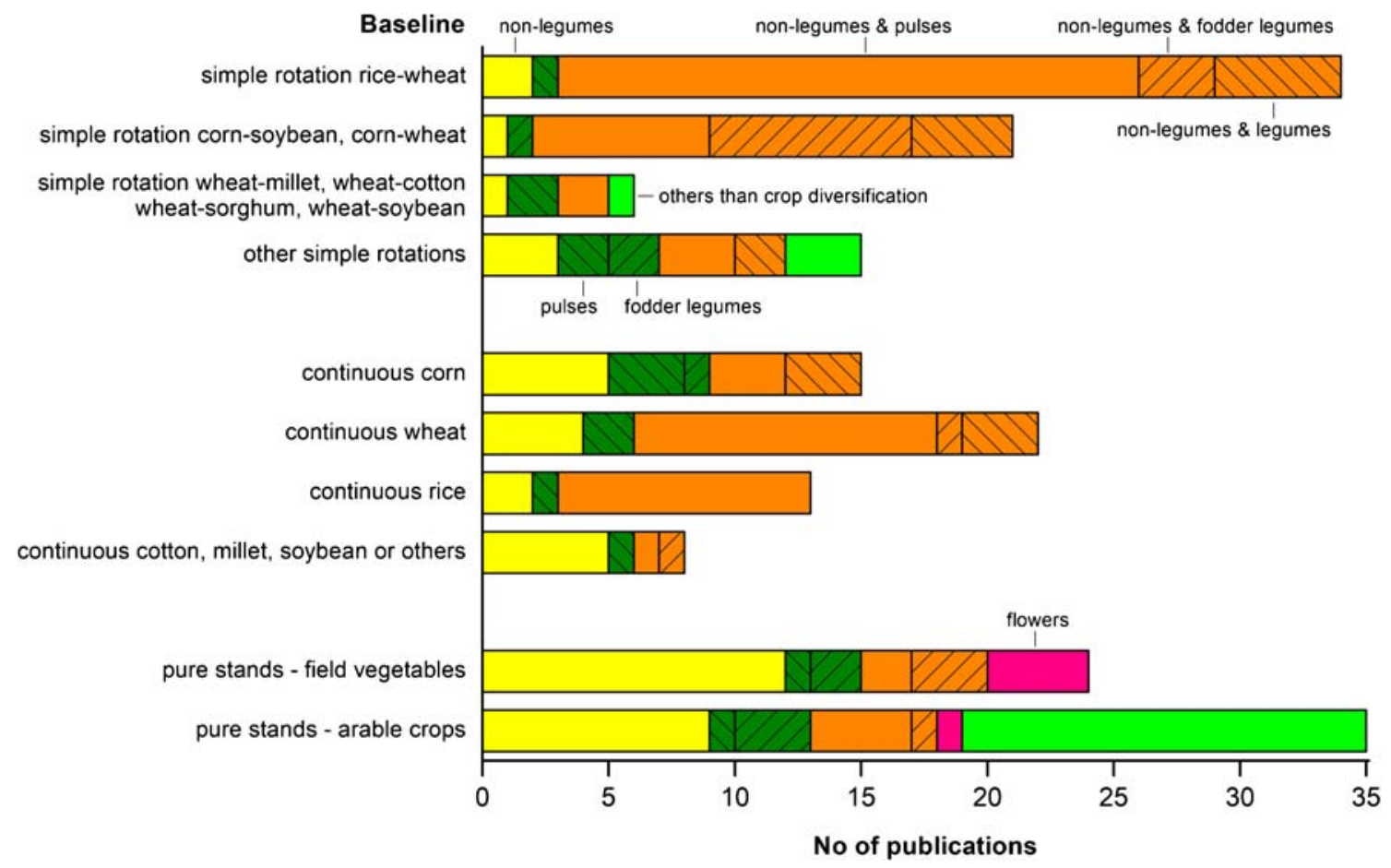

Fig. 6 Number of publications on crop diversification experiments broken down by baselines and groups of crops used for diversification (total $n=193$ ) 
Diversification that was not explicitly based on the introduction of a new crop occurred only in $10 \%$ of the experiments, almost exclusively in pure stands of arable crops, some in other simple crop rotations. In these cases, the diversification measures comprise two approaches: replacement of the genetically homogeneous baseline crop by variety mixtures of this crop or mixtures of pure stands of widespread baseline crops of a region on the same field.

\subsection{Agronomic measures accompanying crop diversification}

In the publications analysed, we found the following groups of agronomic measures (Table 6) that were tested additionally to crop diversification or - in some cases - exclusively.

In $22 \%$ of the experiments, the introduction of new crops or variety mixtures (Fig. 7a) was not accompanied by diversifying agronomic measures (Fig. 7a). In $71 \%$ of the experiments, crop diversification went along with at least one additional agronomic measure like variation of cropping patterns; seeding or harvesting time; weed, pest or fertilizer treatment; soil tillage; irrigation or integration fodder production or animals into arable farming (Fig. 7b). In 58\% of these, experiments were tested one, in 33\% two and in 9\% three diversifying agronomic measures.

The introduction of only a new crop was most important in rice-wheat, corn-soybean or wheat and continuous wheat and continuous rice, variety mixtures only as single diversification measure were tested in pure stands of arable crops, as additional measure in combination with others in continuous rice and in rice-wheat experiments.

In all baselines, the variation of growing patterns was an agronomic measure to obtain spatial diversification within a field, more importantly in pure stands of arable crops and field vegetables, and to a lower extent in continuous corn and rice. Variation of cropping patterns was implemented by intercropping, e.g. pulses, fodder legumes or vegetables or by establishing spots or borders with flowering plants or herbs (Fig. 7b). Especially in experiments with corn-soybean or wheat and to a lesser extent in experiments with continuous wheat, continuous corn and with pure stands of vegetables, different levels of inputs were tested. The variation of tillage systems was an important issue in continuous wheat, in other simple crop rotations and in rice-wheat. Irrigation was tested in some experiments of rice-wheat, in continuous rice and wheat-millet, cotton etc., but in total irrigation played a minor role as additional measure of diversification. The testing of green manure was an important measure in experiments with rice-wheat, other simple crop rotations, corn-soybean or wheat, continuous corn and in pure stands of vegetables. Only in rice-wheat rotations the introduction of fodder production for animals was an additional and important measure of diversification.

In many publications, it was hard to know if the term diversification is restricted to the introduction of a new crop or if additional agronomic measures are also regarded as part of the diversification approach. Some articles used the term diversification exclusively for the introduction of a new crop (crop diversification); in others, the term diversification also was applied to diversification by additional agronomic measures ('diversification by measure').

In fact, in $7 \%$ of the experiments, diversification was obtained by only introducing new agronomic measures. This diversification approach was chosen especially for pure stands of arable crops and to a small extent for other simple crop rotations. Especially one diversification measure without crop diversification was tested: the variation of growing patterns, where a new spacing of 'old' crops was subject to analysis. Other measures like variation of tillage or cultivation period, irrigation or input management played a minor role in experiments restricted to diversification by agronomic measures.

Table 6 Accompanying agronomic measures to crop diversification (groups) or alone

Groups of agronomic measures accompanying crop diversification and their characterisation

Variety mixture(s)

Pattern

Cultivation period

Input management

Soil tillage

Irrigation

Green manure

Fodder production

Livestock
Cropping of different varieties on a single field in mixture or in strips

Variation of cropping patterns of the baseline crop (e.g. row spacing) or introducing a new crop (e.g. mixed or intercropping, as border)

Variation of seeding and/or harvesting time

Variation of fertilization, pest or weed management in time, kind and amount including ecological or conventional variants

Tillage system(s) (e.g. no till, conserving, plough, conventional)

Variation of irrigation in time, kind and amount

Additional utilisation of 'old' and/ or new crops (e.g. soil cover, fodder, incorporation of organic matter)

Utilisation of old and/or new crops as fodder for livestock

Integration of animals in arable farming (e.g. pastures in rotations or grazing of catch crops) 


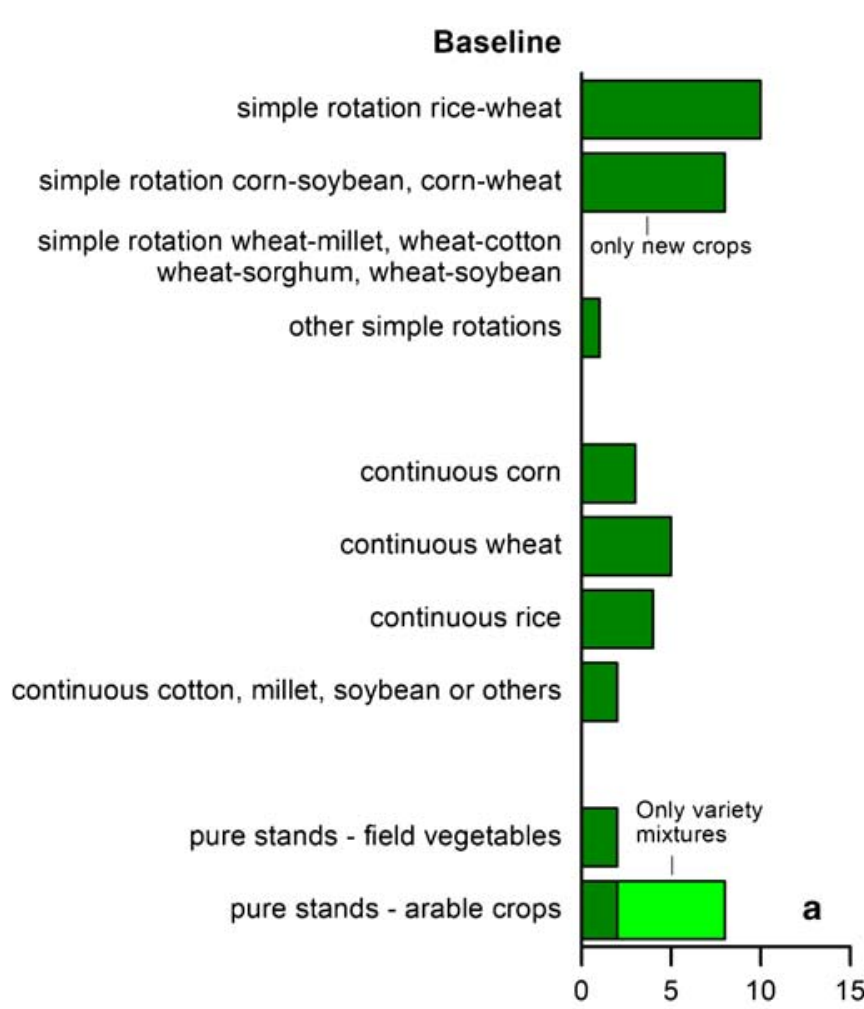

Fig. 7 Number of crops and variety mixtures tested without additional measures $(\mathbf{a}, n=43)$ or in combination with at least one additional measure (b, $n=136)$ broken down by baselines and groups of measures $(n=179)$. Many publications $(n=136)$ refer to experiments with at least

Table 7 Groups of target variables and their characterization (examples)

\section{Group of target Characterisation: examples}

variables

$\begin{array}{ll}\text { 'Agronomic' } & \begin{array}{c}\text { Agricultural production: yield, ingredients, } \\ \text { phenological data }\end{array} \\ \text { 'Economic' } & \text { Economic performance: income, net returns, costs } \\ \text { 'Nutrients' } & \text { Nutrient cycling, nutrient balance, N-fixation, water } \\ \text { 'Pests' } & \begin{array}{l}\text { Pests, diseases, weeds, weed seeds } \\ \text { 'Soils' }\end{array} \\ & \begin{array}{l}\text { Biotic and abiotic soil parameters like mycorrhiza or } \\ \text { organic matter }\end{array} \\ \text { 'Risk' } & \begin{array}{l}\text { Production risk and resilience of cropping systems } \\ \text { 'Food webs' }\end{array} \\ \begin{array}{l}\text { Population dynamics of pests and/ or predators; } \\ \text { birds }\end{array} \\ \text { 'Others' } & \begin{array}{l}\text { Energy input, greenhouse gases, ground water } \\ \text { 'Whole system' }\end{array} \\ & \begin{array}{l}\text { Variables describe a wide range of parameters: } \\ \text { agronomic, economic, performance, soil }\end{array} \\ & \text { parameters, environmental impact, labour, risk }\end{array}$
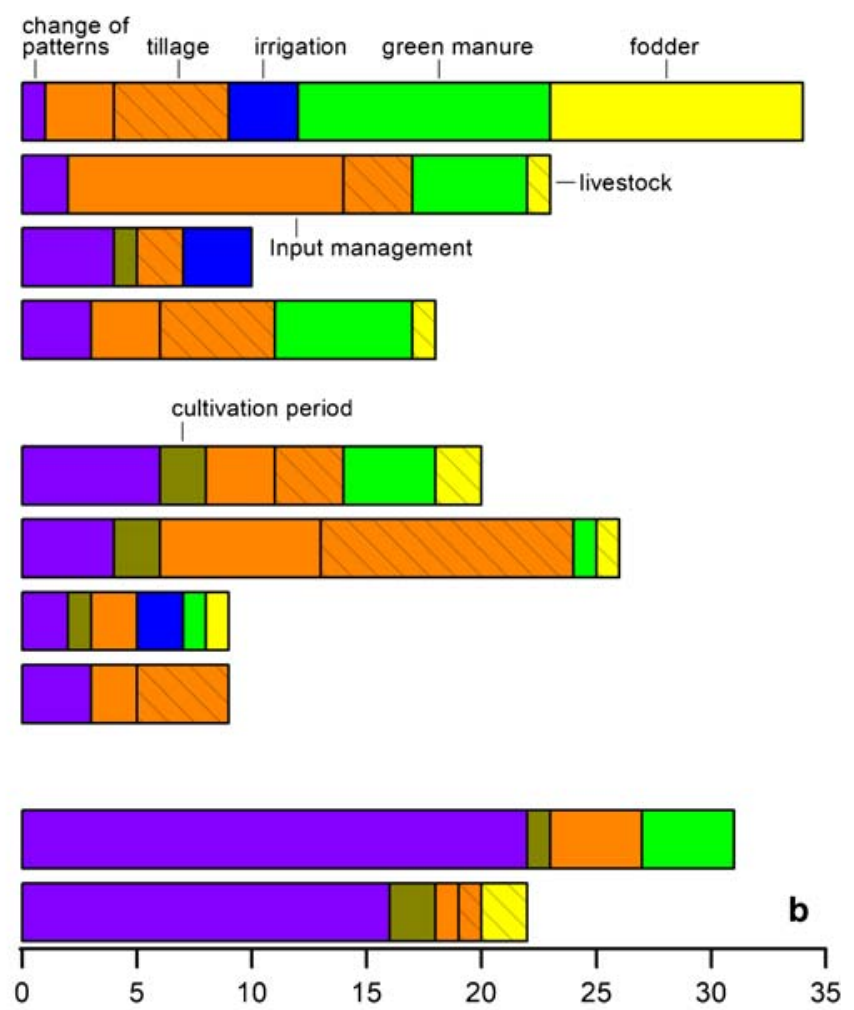

No of crops/ measures tested

one accompanying measure to crop diversification. Thus, the number of cases $(n=245)$ shown in the figure exceeds the number of publications. Experiments with measures 'others than crop diversification' are not presented in Fig. $7(n=14)$

\subsection{Target variables of the crop diversification experiments}

It was one goal of our review to compile target variables that were used in the analysed primary studies to assess the impact of crop diversification, whereas we did not quantify the impact itself. We found the following groups of target variables listed in Table 7.

About $10 \%$ of the experiments concentrated only on agronomic and or economic target variables, only half of them raising both. Forty-five per cent analysed mainly biotic and abiotic target variables without integrating agronomic or economic aspects (Fig. 8). The remaining $45 \%$ of the experiments analysed the impact of crop diversification measures both on agronomic and/or economic target variables and on abiotic and/or biotic variables describing the impact on the production site, e.g. soil and/or the environment, e.g. ground water or food webs (Fig. 9). There was no obvious preference for certain variables as a function of the different baselines - with two exceptions: first, experiments in pure stands of both field vegetables and arable crops focussed very much on food webs (mostly insects), in arable crops additionally on pests, diseases and weeds (Fig. 8); and second, a small share of experiments 


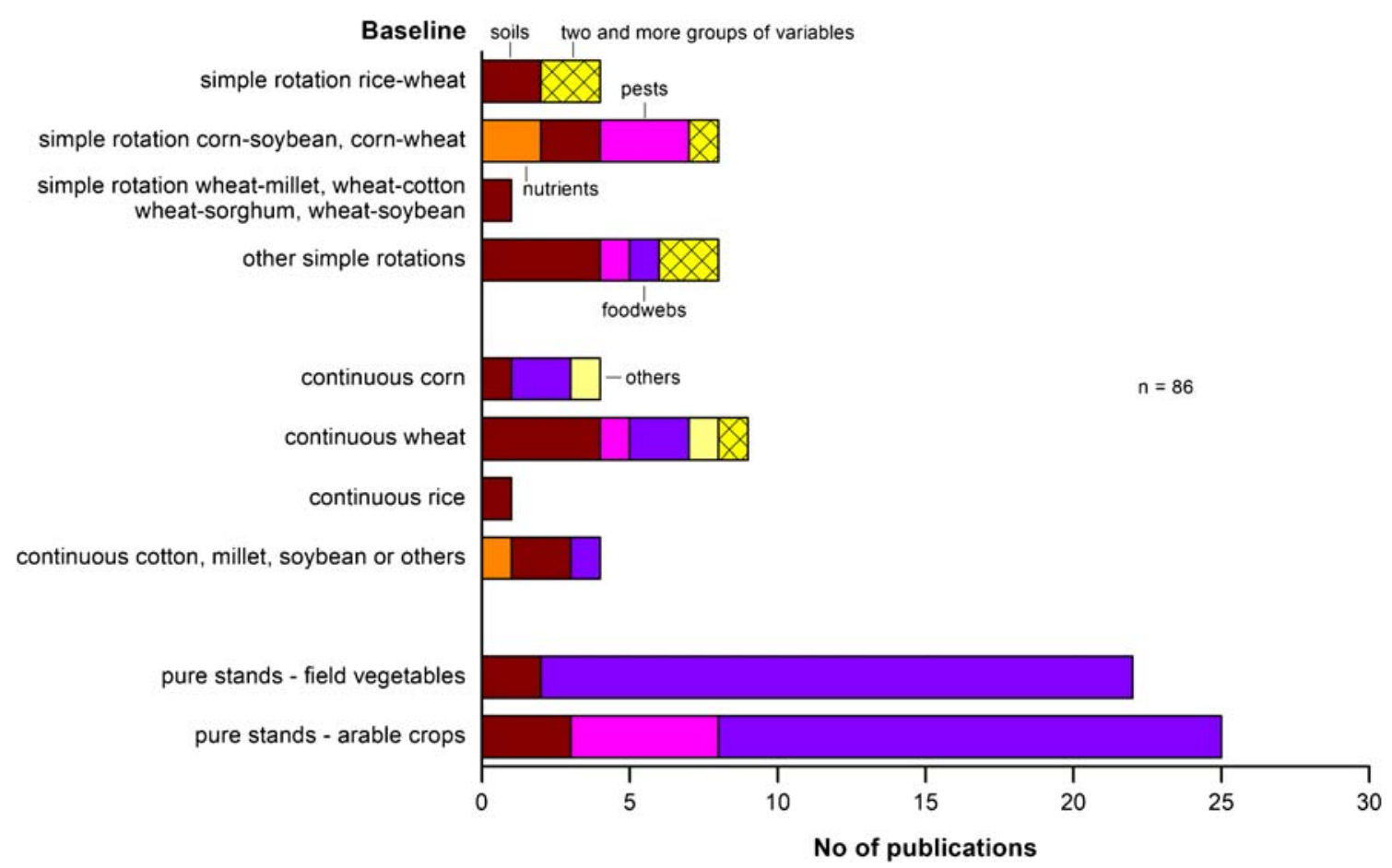

Fig. 8 Number of publications on crop diversification experiments analysing only non-agronomic/non-economic groups of target variables broken down by baselines and groups of target parameters

analysed two or more groups of target variables beside agronomic and economic parameters or even tried to characterize the 'whole system' (Fig. 9). This applies both to continuous corn and corn-soybean or wheat baselines and to experiments with 'continuous rice' or rice--wheat rotations (Fig. 9); the first ones are mostly located in North America and the second ones in India.

In any other cases, experiments only focussed on one group of target variables while neglecting others (Figs. 8 and 9). It is difficult to get an idea about the reasons why which

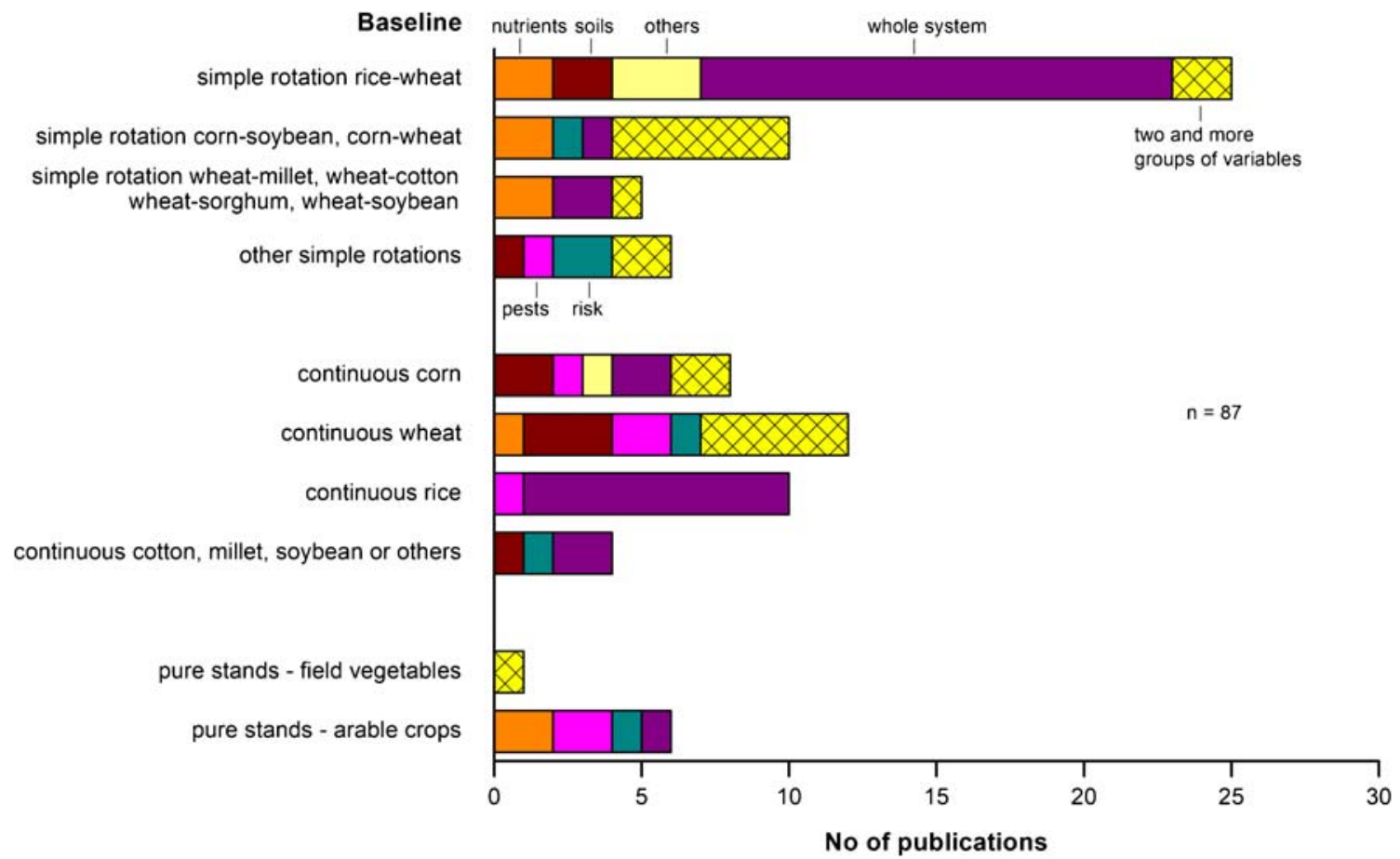

Fig. 9 Number of publications on crop diversification experiments analysing both agronomic/economic and non-agronomic/economic groups of target variables broken down by 'baselines' and groups of target parameters 
parameters in which experiment have been selected. We suppose that the selection of the respective target variables depends very much on the professional focus of the experimenters and the common agreement of a particular scientific school.

\section{The lack of a concept of crop diversification}

Though we found thousands of scientific papers on crop diversification like crop rotation or intercropping in the field of agronomy (Table 1), only a fraction of these publications relate to diversification as a concept. Despite our global assessment on the use of crop diversification in the literature, we did not find a theoretical and overarching concept of crop diversification. Hence, the implementation of diversification experiments is not concise concerning the problems to be solved, the baseline situation to allow comparisons, the kind and number of crop diversification measures applied and the target variables analysed.

In many of the analysed publications, authors did not explain explicitly under which circumstances and prerequisites which measures of crop diversification would be most efficient to solve a given problem (problem definition). Our analysis also showed that most articles do not describe explicitly the current farming practice of specialized or non-diversified farming (baseline definition). This information is relevant to allow comparisons with the novel diversified systems. Only a few studies have been repeated at more than one site or even in different agroecological zones which limits the applicability (definition of scale). The design of the experiments is often insufficiently explained to understand why certain measures are tested and why not others (experimental design). Not all of the studies have a clear definition of the target parameters to be analysed (define impact), and only 50\% of them raised both agronomic/economic and ecological parameters; it is necessary to evaluate crop diversification both from an agronomic and ecological point of view and to compare it to the baseline. In most cases, the implementation of experiments seems very much driven by practical problems in agriculture of a given country or region We suspect that in these cases, the tested diversification steps were selected by local experts to answer applied problems. In other cases studied, diversification steps are selected by researchers who have set up the experiments for a pressing research question. Hence, such experiments are highly context-specific and based on a broad base of regional experience. They surely may help to solve specific local or regional problems, but it is difficult to compare the different studies and generalise from the results of these studies on diversification. This would be necessary to contribute efficiently to the development of scientifically based and more importantly transferable approaches to crop diversification. In addition, generalisation also is made difficult by the fact that
$76 \%$ of the experiments were executed in five countries and $56 \%$ in only two (USA and India). Furthermore, most of the experiments within a country are restricted to one agroecological zone.

From the range of problems to be addressed by crop diversification studies, we can identify three types of perspectives that motivated the respective studies:

The first one is based on an explicit theoretical concept: e.g. diversification is useful to improve biological pest control (Hooks and Johnson 2001; Haro et al. 2018). This perspective applies for most of the experiments that analyse the possibilities to influence and understand interactions in food webs by crop diversification ('agroecological perspective'). The second one tries to find alternative or additional agricultural products (Kachroo et al. 2014; Jacob et al. 2016) that might rise and stabilize farmer's income (e.g. many of the diversification experiments in India - rice-wheat) ('agro-economic perspective'). The third perspective is driven by the fact that current cropping practices go along with stagnating yields, deterioration of soils, increase of environmental problems, rise of pests, diseases or weed problems following an 'agronomic-ecological' perspective (Liebman and Davis 2000; Hati et al. 2013; Sharma et al. 2017). Perspective 1 mostly focusses on furthering the understanding of agroecological principles; most of these studies are made in diversified pure stands and do not consider the effect of preliminary crops. The focus of perspectives 2 and 3 is mostly on stabilizing income, developing new cropping methods and/or to reduce environmental problems.

A well-defined concept of crop diversification is a prerequisite to make results among studies comparable and to avoid arbitrary use of the term diversification. Likewise, Beillouin et al. (2019b) state that 'most of the meta-analyses studied cannot be considered fully transparent and reproducible'. A defined concept should clarify what is understood by diversification, what types of measures are regarded as diversification, which target parameters are useful to assess the impact of diversification and what the relevant scales of investigation are. The concept of crop diversification should be framed along five elements, following the limitations identified in the analysed literature:

1. Problem definition: Describe the reason for diversification and the diversification target

2. Baseline definition: Characterise the baseline system to be diversified.

3. Scale definition: Describe the target area of diversification: field, farm or landscape and expected interactions, define the system boundary.

4. Experimental design: Explain the decisions on diversification treatments, crop choice, mixtures, rotations etc. and the target variables. Ensure comparison with the baseline.

5. Define impact: Systematically compare the baseline with diversified systems in absolute and relative terms for 
defined impact variables to evaluate the effects of the diversification measures. To do that, a minimum set of agronomic, economic and ecological target variables is necessary.

This framework can be a starting point for a guideline which supports experimentalists to answer the main question on diversification. Some studies such as Plaza-Bonilla et al. (2017) provide most of the aspects in our framework in more or less detail. They described the problem of current farming in southwestern France, as the high environmental degradation due to the uncoupling of carbon and $\mathrm{N}$ cycles in specialized cropping systems (problem definition). Current farming is represented by a cereal-sunflower rotation without legumes (baseline definition); the analysis is conducted at the rotational level (scale definition) and the experiment explores the diversification effect of grain legumes with and without cover crops (experimental design). To describe the system and its impact sufficiently, both agronomic, e.g. yield, grain protein concentration and ecological variables, e.g. soil water, mineral Ncontent (Plaza-Bonilla et al. 2018) were quantified and compared with the baseline system (define impact).

\section{Methodological considerations}

In contrast to many other studies, we have taken an agronomic perspective on crop diversification as a basis for this review. Our focus was on diversification and not on diversity. That means our scientific question differed considerably to that in diversity studies, e.g. Haro et al. (2018), Buhk et al. (2017) and Wezel et al. (2014). Diversity studies analyse diversity of cropping or natural systems concerning flora and fauna and ask for the main characteristics of these systems. That means most studies on diversity compare different levels of diversity as a result of diversification. They do not analyse the initial situation, the necessary steps and the importance of time to achieve the level of diversity they found. Implicitly, they assume that it is sufficient to establish cropping systems that show the found characteristics of diversity to be sustainable, environmentally friendly or biodiversity supporting though some authors emphasise that the performance of diversification practices is highly context-specific (Rosa-Schleich et al. 2019; Kremen and Miles 2012).

We are well aware that our review shows some important limits; some of them can be explained by the topic itself: since there is no consensus on what crop diversification comprises, it was not possible to compile a complete list of adequate search terms. Hence, we may not have found some measures of crop diversification that have been addressed in other analysis, e.g. Beillouin et al. (2019a). Furthermore, we excluded arbitrarily some diversification measures like 'agroforestry' or 'intergraded crop-livestock systems'. Also, because our analysis is based mainly on information in title, abstract and keywords, considering information of the whole articles might have led to other results at least with regard to quantity. Furthermore, the low percentage of found publications on the topic suggests that probably many agronomic experiments are carried out with 'diversification in mind' without labelling them with diversification, e.g. Reckling et al. (2016) and Stein-Bachinger et al. (2015). It is therefore not surprising that other review studies on crop diversification found more experiments, e.g. the almost 20 -fold higher number of primary studies in the meta-analysis by Beillouin et al. (2019a). And last but not least, our review is restricted to crop diversification at field level.

\section{Conclusion}

Our analysis reveals that so far, there is no theoretically well-founded concept of crop diversification. The current use of the term diversification depends very much on the country, regional current problems caused by agriculture, the focus of the scientific discipline, the particular scientific school and local expert knowledge, and it is restricted to relatively few baselines and agroecological situations.

If crop diversification is to be developed as a tool for improving cropping systems, developing novel value-chains and providing other socio-economic benefits, it is necessary to develop a shared conceptual understanding. Without such concept, the numerous results of the different scientific communities on the topic (diversification) will use different terms for the same thing or same terms for different things (e.g. diversification, diversity, crop rotation, mixed cropping). This will prevent synergetic effects and generalisation of results.

We suggest first steps towards a conceptual framework on crop diversification expletively distinguishing and providing information on (i) problem definition, (ii) baseline definition, (iii) scale definition, (iv) characterisation of the experimental design including a minimum set of target variables and (v) defining the impact systematically to assess and report the effects of the diversification measures.

Acknowledgments MR was funded by the Deutsche Forschungsgemeinschaft (DFG, German Research Foundation) 420661662 .

Authors' contribution Conceptualization and methodology: J.H., M. R and F.E. Data handling and analysis: J.H. Writing — original draft, review and editing: J.H., M.R. and F.E.

Funding Information Open Access funding provided by Projekt DEAL. 


\section{Compliance with ethical standards}

Conflict of interest The authors declare that they have no conflict of interest.

Open Access This article is licensed under a Creative Commons Attribution 4.0 International License, which permits use, sharing, adaptation, distribution and reproduction in any medium or format, as long as you give appropriate credit to the original author(s) and the source, provide a link to the Creative Commons licence, and indicate if changes were made. The images or other third party material in this article are included in the article's Creative Commons licence, unless indicated otherwise in a credit line to the material. If material is not included in the article's Creative Commons licence and your intended use is not permitted by statutory regulation or exceeds the permitted use, you will need to obtain permission directly from the copyright holder. To view a copy of this licence, visit http://creativecommons.org/licenses/by/4.0/.

\section{References}

Altieri MA, Nicholls CI, Henao A, Lana MA (2015) Agroecology and the design of climate change-resilient farming systems. Agron Sustain Dev 35(3):869-890. https://doi.org/10.1007/s13593-015-0285-2

Barbieri P, Pellerin S, Nesme T (2017) Comparing crop rotations between organic and conventional farming. Sci Rep 7(1). https://doi.org/10. 1038/s41598-017-14271-6

Barot S, Allard V, Cantarel A, Enjalbert J, Gauffreteau A, Goldringer I, Lata JC, Le Roux X, Niboyet A, Porcher E (2017) Designing mixtures of varieties for multifunctional agriculture with the help of ecology. A review. Agron Sustain Dev 37(2):1-20. https://doi.org/ 10.1007/s13593-017-0418-x

Bedoussac L, Journet E-P, Hauggaard-Nielsen H, Naudin C, CorreHellou G, Jensen ES, Prieur L, Justes E (2015) Ecological principles underlying the increase of productivity achieved by cereal-grain legume intercrops in organic farming. A review. Agron Sustain Dev 35(3):911-935. https://doi.org/10.1007/s13593-014-0277-7

Beillouin D, Ben-Ari T, Makowski D (2019a) A dataset of meta-analyses on crop diversification at the global scale. Data Brief 24:103898. https://doi.org/10.1016/j.dib.2019.103898

Beillouin D, Ben-Ari T, Makowski D (2019a) Evidence map of crop diversification strategies at the global scale. EnvironResLett 14 (12). https://doi.org/10.1088/1748-9326/ab4449

Bianchi FJJA, Booij CJH, Tscharntke T (2006) Sustainable pest regulation in agricultural landscapes: a review on landscape composition, biodiversity and natural pest control. Proc R Soc B Biol Sci 273(1595):1715-1727. https://doi.org/10.1098/rspb.2006.3530

Bommarco R, Kleijn D, Potts SG (2013) Ecological intensification: harnessing ecosystem services for food security. Trends Ecol Evol 28(4):230-238. https://doi.org/10.1016/j.tree.2012.10.012

Bowles TM, Atallah SS, Campbell EE, Gaudin ACM, Wieder WR, Grandy AS (2018) Addressing agricultural nitrogen losses in a changing climate. Nat Sustain 1(8):399-408. https://doi.org/10. 1038/s41893-018-0106-0

Buhk C, Alt M, Steinbauer MJ, Beierkuhnlein C, Warren SD, Jentsch A (2017) Homogenizing and diversifying effects of intensive agricultural land-use on plant species beta diversity in Central Europe - a call to adapt our conservation measures. Sci Total Environ 576:225233. https://doi.org/10.1016/j.scitotenv.2016.10.106

Cardinale BJ, Wright JP, Cadotte MW, Carroll IT, Hector A, Srivastava DS, Loreau M, Weis JJ (2007) Impacts of plant diversity on biomass production increase through time because of species complementarity. Proc Natl Acad Sci 104(46):18123-18128. https://doi.org/10. 1073/pnas.0709069104
Connor DJ, Loomis RS, Cassman KG (2011) Crop ecology: productivity and management in agricultural systems. Crop Ecology: Productivity and Management in Agricultural Systems Cambridge University Press doi:https://doi.org/10.1017/CBO9780511974199

Davis AS, Hill JD, Chase CA, Johanns AM, Liebman M (2012) Increasing cropping system diversity balances productivity, profitability and environmental health. PLoS One 7(10). https://doi.org/ 10.1371/journal.pone.0047149

Fausti SW (2015) The causes and unintended consequences of a paradigm shift in corn production practices. Environ Sci Pol 52:41-50. https://doi.org/10.1016/j.envsci.2015.04.017

Feliciano D (2019) A review on the contribution of crop diversification to sustainable development goal 1 "no poverty" in different world regions. Sustain Dev 27(4):795-808. https://doi.org/10.1002/sd.1923

Fischer J, Böhm H, He $\beta$ J (2020) Maize-bean intercropping yields in Northern Germany are comparable to those of pure silage maize. Eur J Agron 112. https://doi.org/10.1016/j.eja.2019.125947

Frison EA, Cherfas J, Hodgkin T (2011) Agricultural biodiversity is essential for a sustainable improvement in food and nutrition security. Sustainability 3(1):238-253. https://doi.org/10.3390/su3010238

Garbach K, Milder JC, DeClerck FAJ, Montenegro de Wit M, Driscoll L, Gemmill-Herren B (2017) Examining multi-functionality for crop yield and ecosystem services in five systems of agroecological intensification. Int J Agric Sustain 15(1):11-28. https://doi.org/10. 1080/14735903.2016.1174810

Geels FW (2011) The multi-level perspective on sustainability transitions: responses to seven criticisms. Environ Innov Soc Transit 1(1):24-40. https://doi.org/10.1016/j.eist.2011.02.002

Gross K, Cardinale BJ, Fox JW, Gonzalez A, Loreau M, Polley HW, Reich PB, Ruijven J (2014) Species richness and the temporal stability of biomass production: a new analysis of recent biodiversity experiments. Am Nat 183(1):1-12. https://doi.org/10.1086/673915

Haro MM, Silveira LCP, Wilby A (2018) Stability lies in flowers: plant diversification mediating shifts in arthropod food webs. PLoS One 13(2). https://doi.org/10.1371/journal.pone.0193045

Hati KM, Chaudhary RS, Mandal KG, Misra AK, Singh RK, Wani SP, Singh P, Pathak P (2013) Effect of land management and cropping systems on runoff, soil loss, soil water dynamics and crop yield in a vertisol of Central India. J Indian Soc Soil Sci 61(2):79-88

Hatt S, Boeraeve F, Artru S, Dufrêne M, Francis F (2018) Spatial diversification of agroecosystems to enhance biological control and other regulating services: an agroecological perspective. Sci Total Environ 621:600-611. https://doi.org/10.1016/j.scitotenv.2017.11.296

Haughey E, Suter M, Hofer D, Hoekstra NJ, McElwain JC, Lüscher A, Finn JA (2018) Higher species richness enhances yield stability in intensively managed grasslands with experimental disturbance. Sci Rep 8(1):15047. https://doi.org/10.1038/s41598-018-33262-9

Hole DG, Perkins AJ, Wilson JD, Alexander IH, Grice PV, Evans AD (2005) Does organic farming benefit biodiversity? Biol Conserv 122(1):113-130. https://doi.org/10.1016/j.biocon.2004.07.018

Hondrade RF, Hondrade E, Zheng L, Elazegui F, Duque JALJE, Mundt CC, Vera Cruz CM, Garrett KA (2017) Cropping system diversification for food production in Mindanao rubber plantations: a rice cultivar mixture and rice intercropped with mungbean. PeerJ 2017(2). https://doi.org/10.7717/peerj.2975

Hooks CRR, Johnson MW (2001) Broccoli growth parameters and level of head infestations in simple and mixed plantings: impact of increased flora diversification. Ann Appl Biol 138(3):269-280. https://doi.org/10.1111/j.1744-7348.2001.tb00112.x

Isbell F, Adler PR, Eisenhauer N, Fornara D, Kimmel K, Kremen C, Letourneau DK, Liebman M, Polley HW, Quijas S, SchererLorenzen M (2017) Benefits of increasing plant diversity in sustainable agroecosystems. J Ecol 105(4):871-879. https://doi.org/10. $1111 / 1365-2745.12789$

Jacob D, Mathew T, John J, Rani B, Sukumari P (2016) On-farm farmers' participatory evaluation of intensification of rice (Oryza sativa)- 
rice-fallow system with vegetables in summer under humid tropical irrigated lowlands. Indian J Agron 61(3):281-285

Kachroo D, Thakur NP, Kour M, Kumar P, Sharma R, Khajuria V (2014) Diversification of rice (Oryza sativa)-based cropping system for enhancing productivity and employment. Indian J Agron 59(1):21-25

Kahiluoto H, Kaseva J, Balek J, Olesen JE, Ruiz-Ramos M, Gobin A, Kersebaum KC, Takáč J, Ruget F, Ferrise R, Bezak P, Capellades G, Dibari C, Mäkinen H, Nendel C, Ventrella D, Rodríguez A, Bindi M, Trnka M (2019) Decline in climate resilience of European wheat. Proc Natl Acad Sci 116(1):123-128. https://doi.org/10.1073/pnas. 1804387115

Kleijn D, Kohler F, Báldi A, Batáry P, Concepción ED, Clough Y, Díaz M, Gabriel D, Holzschuh A, Knop E, Kovács A, Marshall EJP, Tscharntke T, Verhulst J (2012) On the relationship between farmland biodiversity and land-use intensity in Europe. Proc R Soc B Biol Sci 276(1658): 903-909. https://doi.org/10.1098/rspb.2008.1509

Kremen C, Miles A (2012) Ecosystem services in biologically diversified versus conventional farming systems: benefits, externalities, and tradeoffs. Ecol Soc 17(4). https://doi.org/10.5751/ES-05035-170440

Kremen C, Iles A, Bacon C (2012) Diversified farming systems: an agroecological, systems-based alternative to modern industrial agriculture. Ecol Soc 17(4). https://doi.org/10.5751/ES-05103-170444

Kumar R, Shambhavi S, Beura K, Kumar S, Singh RG (2017) Soil microbial budgeting as influenced by contrasting tillage and crop diversification under rice based cropping systems in Inseptisol of Bihar. J Pure Appl Microbiol 11(1):539-547. https://doi.org/10. 22207/JPAM.11.1.71

Landis DA (2017) Designing agricultural landscapes for biodiversitybased ecosystem services. Basic Appl Ecol 18:1-12. https://doi. org/10.1016/j.baae.2016.07.005

Lichtenberg EM, Kennedy CM, Kremen C, Batáry P, Berendse F, Bommarco R, Bosque-Pérez NA, Carvalheiro LG, Snyder WE, Williams NM, Winfree R, Klatt BK, Åström S, Benjamin F, Brittain C, ChaplinKramer R, Clough Y, Danforth B, Diekötter T, Eigenbrode SD, Ekroos J, Elle E, Freitas BM, Fukuda Y, Gaines-Day HR, Grab H, Gratton C, Holzschuh A, Isaacs R, Isaia M, Jha S, Jonason D, Jones VP, Klein AM, Krauss J, Letourneau DK, Macfadyen S, Mallinger RE, Martin EA, Martinez E, Memmott J, Morandin L, Neame L, Otieno M, Park MG, Pfiffner L, Pocock MJO, Ponce C, Potts SG, Poveda K, Ramos M, Rosenheim JA, Rundlöf M, Sardiñas H, Saunders ME, Schon NL, Sciligo AR, Sidhu CS, Steffan-Dewenter I, Tscharntke T, Veselý M, Weisser WW, Wilson JK, Crowder DW (2017) A global synthesis of the effects of diversified farming systems on arthropod diversity within fields and across agricultural landscapes. Glob Chang Biol 23(11):4946-4957. https://doi.org/10.1111/gcb.13714

Liebman M, Davis AS (2000) Integration of soil, crop and weed management in low-external-input farming systems. Weed Res 40(1): 27-47. https://doi.org/10.1046/j.1365-3180.2000.00164.x

Liu K, Johnson EN, Blackshaw RE, Hossain Z, Gan Y (2019) Improving the productivity and stability of oilseed cropping systems through crop diversification. Field Crop Res 237:65-73. https://doi.org/10. 1016/j.fcr.2019.03.020

Malézieux E, Crozat Y, Dupraz C, Laurans M, Makowski D, OzierLafontaine H, Rapidel B, De Tourdonnet S, Valantin-Morison M (2009) Mixing plant species in cropping systems: concepts, tools and models: a review. In: Sustainable Agriculture. Springer Netherlands, pp 329-353. doi:https://doi.org/10.1007/978-90-481-2666-8_22

Meynard J-M, Charrier F, Fares M, Le Bail M, Magrini M-B, Charlier A, Messéan A (2018) Socio-technical lock-in hinders crop diversification in France. Agron Sustain Dev 38(5):54-13. https://doi.org/10. 1007/s13593-018-0535-1

Phelan P, Moloney AP, McGeough EJ, Humphreys J, Bertilsson J, O'Riordan E, O'Kiely P (2015) Forage legumes for grazing and conserving in ruminant production systems. Crit Rev Plant Sci 34. https://doi.org/10.1080/07352689.2014.898455

Plaza-Bonilla D, Nolot JM, Raffaillac D, Justes E (2017) Innovative cropping systems to reduce $\mathrm{N}$ inputs and maintain wheat yields by inserting grain legumes and cover crops in southwestern France. Eur J Agron 82:331-341. https://doi.org/10.1016/j.eja.2016.05.010

Plaza-Bonilla D, Nogué-Serra I, Raffaillac D, Cantero-Martínez C, Justes É (2018) Carbon footprint of cropping systems with grain legumes and cover crops: A case-study in SW France. Agric Syst 167:92102. https://doi.org/10.1016/j.agsy.2018.09.004

Ponisio LC, Ehrlich PR (2016) Diversification, yield and a new agricultural revolution: problems and prospects. Sustainability $8(11)$ https://doi.org/10.3390/su8111118

Raseduzzaman M, Jensen ES (2017) Does intercropping enhance yield stability in arable crop production? A meta-analysis. Eur J Agron 91: 25-33. https://doi.org/10.1016/j.eja.2017.09.009

Reckling M, Hecker J-M, Bergkvist G, Watson C, Zander P, Stoddard F, Eory V, Topp K, Maire J, Bachinger J (2016) A cropping system assessment framework - evaluating effects of introducing legumes into crop rotations. Eur J Agron 76:186-197. https://doi.org/10.1016/j.eja.2015.11.005

Reckling M, Albertsson J, Topp CFE, Vermue A, Carlsson G, Watson C, Justes E, Bergkvist G, Jensen ES (2019) Does cropping system diversification with legumes lead to higher yield stability? Diverging evidence from long-term experiments across Europe. European Conference on Crop Diversification September 18-21 September 2019, Budapest, Hungary

Renard D, Tilman D (2019) National food production stabilized by crop diversity. Nature 571:257-260. https://doi.org/10.1038/s41586-0191316-y

Roesch-McNally GE, Arbuckle JG, Tyndall JC (2018) Barriers to implementing climate resilient agricultural strategies: the case of crop diversification in the U.S. Corn Belt. Glob Environ Chang 48:206-215. https://doi.org/10.1016/j.gloenvcha.2017.12.002

Rosa-Schleich J, Loos J, Mußhoff O, Tscharntke T (2019) Ecologicaleconomic trade-offs of diversified farming systems - a review. Ecol Econ 160:251-263. https://doi.org/10.1016/j.ecolecon.2019.03.002

Rusch A, Chaplin-Kramer R, Gardiner MM, Hawro V, Holland J, Landis D, Thies C, Tscharntke T, Weisser WW, Winquist C, Woltz M, Bommarco R (2016) Agricultural landscape simplification reduces natural pest control: a quantitative synthesis. Agric Ecosyst Environ 221:198-204. https://doi.org/10.1016/j.agee.2016.01.039

Sharma NK, Singh RJ, Mandal D, Kumar A, Alam NM, Keesstra S (2017) Increasing farmer's income and reducing soil erosion using intercropping in rainfed maize-wheat rotation of Himalaya, India. Agric Ecosyst Environ 247:43-53. https://doi.org/10.1016/j.agee.2017.06.026

Stein S, Steinmann HH (2018) Identifying crop rotation practice by the typification of crop sequence patterns for arable farming systems - a case study from Central Europe. Eur J Agron 92:30-40. https://doi. org/10.1016/j.eja.2017.09.010

Stein-Bachinger K, Reckling M, Bachinger J, Hufnagel J, Koker W, Granstedt A (2015) Ecological recycling agriculture to enhance agro-ecosystem services in the Baltic Sea Region: guidelines for implementation. Land 4(3):737-753. https://doi.org/10.3390/ land 4030737

Stoate C, Báldi A, Beja P, Boatman ND, Herzon I, van Doorn A, de Snoo GR, Rakosy L, Ramwell C (2009) Ecological impacts of early 21st century agricultural change in Europe - a review. J Environ Manag 91(1):22-46. https://doi.org/10.1016/j.jenvman.2009.07.005

Therond O, Duru M, Roger-Estrade J, Richard G (2017) A new analytical framework of farming system and agriculture model diversities. A review. Agron Sustain Dev 37(3). https://doi.org/10.1007/s13593017-0429-7 
Tilman D, Cassman KG, Matson PA, Naylor R, Polasky S (2002) Agricultural sustainability and intensive production practices. Nature 418(6898):671-677. https://doi.org/10.1038/nature01014

Tscharntke T, Clough Y, Wanger TC, Jackson L, Motzke I, Perfecto I, Vandermeer J, Whitbread A (2012) Global food security, biodiversity conservation and the future of agricultural intensification. Biol Conserv 151(1):53-59. https://doi.org/10.1016/j.biocon.2012.01.068

Urruty N, Tailliez-Lefebvre D, Huyghe C (2016) Stability, robustness, vulnerability and resilience of agricultural systems. A review. Agron Sustain Dev 36(1):15. https://doi.org/10.1007/s13593-015-0347-5

Vijaya BAV, Baresel JP, Weedon O, Finckh MR (2019) Effects of ten years organic and conventional farming on early seedling traits of evolving winter wheat composite cross populations. Sci Rep 9(1): 9053. https://doi.org/10.1038/s41598-019-45300-1

Watson C, Reckling M, Preissel S, Bachinger J, Bergkvist G, Kuhlman T, Lindström K, Nemecek T, Topp C, Vanhatalo A, Zander Z, Murphy-
Bokern D, Stoddard F (2017) Grain legume production and use in European agricultural systems. Adv Agron 144(1):235-303

Weißhuhn P, Reckling M, Stachow U, Wiggering H (2017) Supporting agricultural ecosystem services through the integration of perennial polycultures into crop rotations. Sustainability 9(12):2267

Wezel A, Casagrande M, Celette F, Vian JF, Ferrer A, Peigné J (2014) Agroecological practices for sustainable agriculture. A review. Agron Sustain Dev 34(1):1-20. https://doi.org/10.1007/s13593-013-0180-7

Yang L-N, Pan Z-C, Zhu W, Wu EJ, He D-C, Yuan X, Qin Y-Y, Wang Y, Chen R-S, Thrall PH, Burdon JJ, Shang L-P, Sui Q-J, Zhan J (2019) Enhanced agricultural sustainability through within-species diversification. Nat Sustain 2(1):46-52. https://doi.org/10.1038/s41893018-0201-2

Publisher's note Springer Nature remains neutral with regard to jurisdictional claims in published maps and institutional affiliations. 